\title{
Recent Developments in Renewable Energy Policies of Turkey
}

\author{
Hasan Saygin ${ }^{1}$ and Füsun Çetin ${ }^{2}$ \\ ${ }^{1}$ Istanbul Aydin University, Engineering and Architecture Faculty \\ 2Istanbul Technical University, Energy Institute \\ Turkey
}

\section{Introduction}

Nowadays, a radical change is taking place in global energy policies. A new energy paradigm consistent with the goal of sustainable development is evolving. The World is in the midst of paradigm shift towards non-carbon based economy. In nature of things, the new energy paradigm has emerged in and is taking root in developed countries. It is however spreading from them to developing countries. Renewable energy constitutes one of the three essential pillars of the new energy paradigm, due to its potentially important role in improving energy security and the decarbonization of global economy. One of the most important implications of this paradigm change is that technological leapfrogging opportunity appears for developing countries having sufficient renewable energy potential. Implementation of the new energy paradigm in developing countries can provide them to develop by avoiding from a repetition of the mistakes of the industrialized countries (Saygin \& Çetin, 2010).

Turkey with huge renewable energy potential is one of these countries having a strong chance of leapfrogging in energy technologies. Although concerns about energy supply security dominates because of rapidly rising energy demand, decision-makers in Turkey are striving to set up secure, environment-friendly and sustainable energy policies parallel to contemporary global energy policies. In this context, it has been made important progress with regard to especially, renewable energy and energy efficiency regulations in the recent years (Saygin \& Çetin, 2010). Present status and potential of renewable energy of Turkey and recent developments in its renewable energy policies are reviewed in the following sections.

\section{Turkey's energy challenges and renewable energy}

Turkey is $17^{\text {th }}$ largest economy of the World. Although its energy use is comparatively low, the Country with rapidly growing economy is one of the fastest growing energy markets in the World. Primary Energy Demand is rapidly increasing, as can be seen from Figure 1. The Country will likely see the fastest medium-to-long term growth in energy demand among the IEA member countries. (IEA, 2009).

Turkey's total final energy consumption of energy was 74 Mtoe in 2008 up by $\% 86$ from 1990. Following its economic growth, energy use in Turkey is expected to roughly double over the next decade, and electricity demand is likely to increase even faster. This implies 
the needs for large energy investments but also measures for ensuring energy security, especially in electricity sector (IEA, 2009).

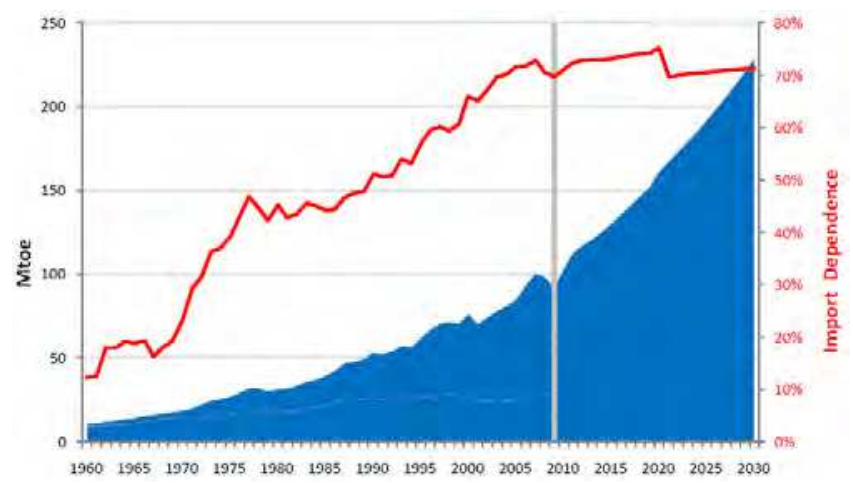

Fig. 1. Evolution of Turkey's Primary Energy Demand and Import Dependence (OME,2008).

Although Turkey is poor in hydrocarbons, its primary energy consumption is mainly based on fossil fuels as seen from Figure 2. Except hydro, renewable resources have been almost untouched up to recently. Under this circumstance, rapidly increasing energy consumption implies rapidly increasing import dependence, as seen also from Figure 1 including for practically all oil and natural gas and most coal. More than about $70 \%$ of the total primary energy consumption in the country is met by imports. It is heavily dependent on foreign fossil fuels and this dependency is one of the most important issue threatening its energy supply security and economy.

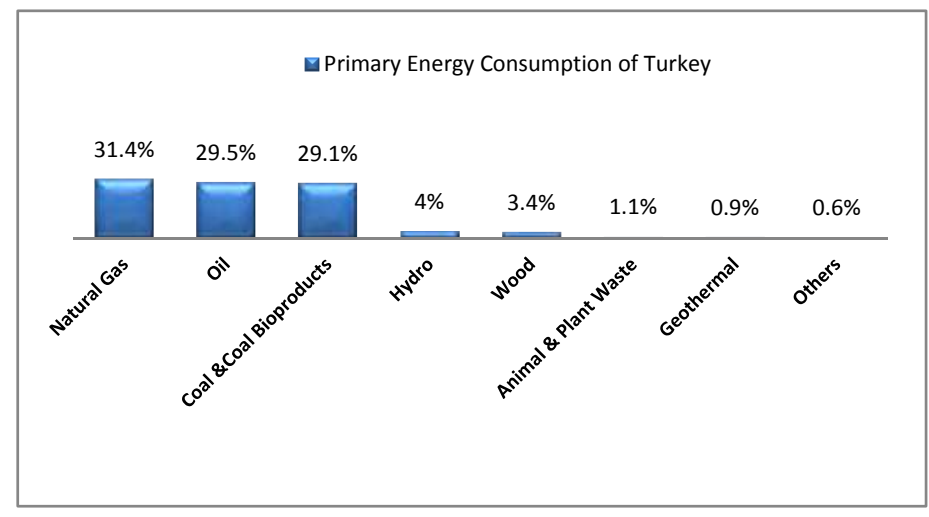

Fig. 2. Primary Energy Consumption of Turkey by Sources (MENR).

Concerns for ensuring sufficient energy supply for growing economy, therefore, dominates in determining energy policies. Hence energy security has a more central place in the energy policy goals in comparison with market reform and environmental protection. This fact may retard the diffusion of the new paradigm in the Country. Likewise, Turkey follows a deliberate policy for new renewables. 
Another challenge rising from largely reliance on fossil fuels is rapidly increasing greenhouse gases emission. Although Turkey have less greenhouse gas emission per Capita than both OECD Countries and transition countries, it has a high rate of increase in emissions since 1990. Energy-related $\mathrm{CO}_{2}$ emission has rapidly increased over last decade also, as illustrated in Figure 3. It is likely to continue to increase fast over the medium and long term, in parallel with significant growth in energy demand (IEA, 2009). This is a another growing concern in the Country.

Turkey has been a Party to the United Nations Framework Convention on climate Change (UNFCCC) since 2004 and to the Kyoto Protocol since 2009. Signing the Kyoto Protocol does not put an additional burden on Turkey until 2012. However, Turkey has undertaken the responsibility of passing the necessary legislation to lay the infrastructure for fighting climate change after 2012. The major issue for the Country is how to contribute to reducing the on global emission without jeopardizing its economic and social development prospects.

Its high energy intensity is another challenge for Turkey. The change in the primary energy density throughout the periods from 1980 to 2005 and from 2000 to 2008 are illustrated in Figure 4(a) and 4(b). In spite of improvement efforts, energy intensity remains high although an improving trend is observed currently.

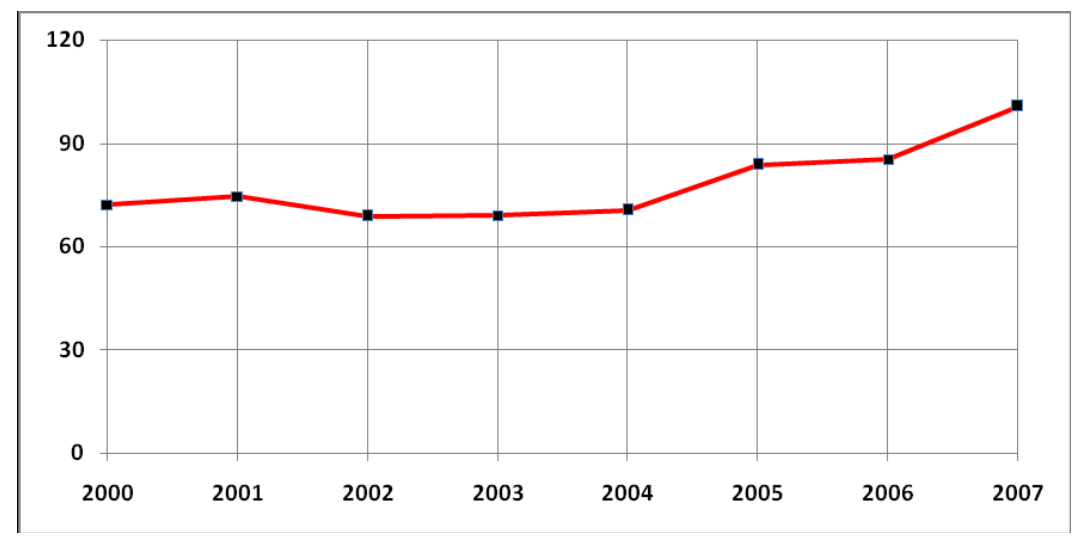

Fig. 3. The $\mathrm{CO}_{2}$ Emission from Electricity Production (2000-2007) (MENR,2010). 


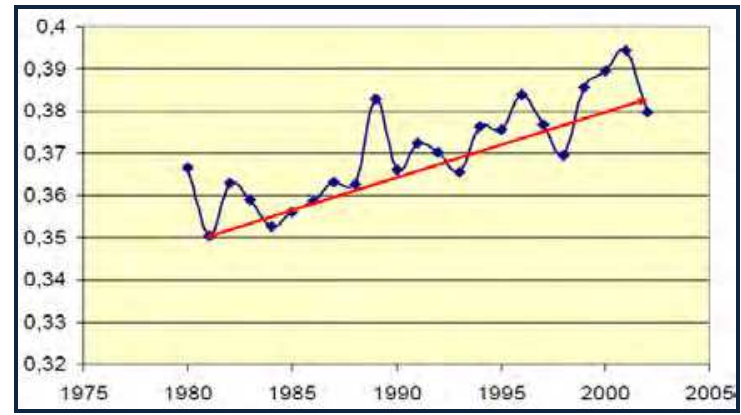

(a)

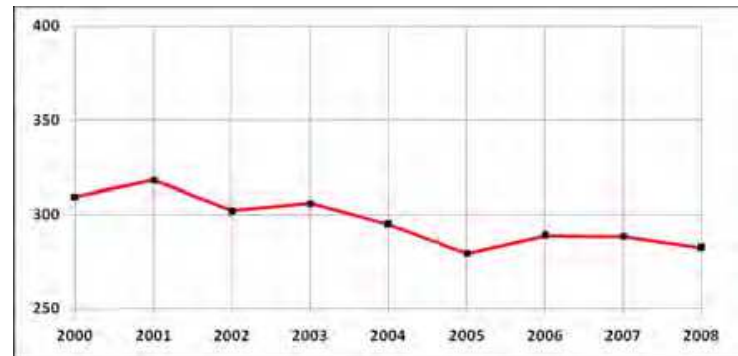

(b)

Fig. 4. Evolution of energy density a) between 1975- 2005 (TOE/ \$ 1000(Çalıkoğlu,2007) b) between 2000-2008 (kg equivalent oil/\$1,000) (MENR,2010)..

As seen from above graphs, it has become near stagnant, after a few decades of rapid increase. High energy intensity is a major obstacle in reducing emissions. But still, Turkey's energy intensity is significantly higher as compared to the other OECD and IEA Countries As seen from Figure 5 (Çalıkoğlu, 2007). That is, Turkey cannot use its energy efficiently.

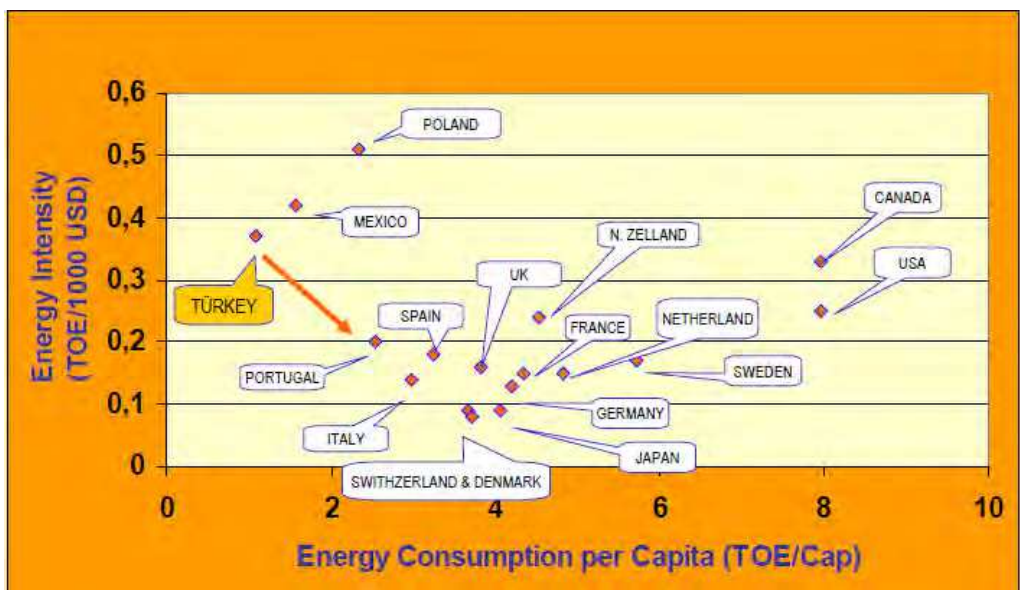

Fig. 5. Energy intensity of Turkey with respect to the other Countries (Çalıkoğlu,2007) 
Total share of renewable in TPES has declined depending on, mainly, decreasing biomass use and the growing role of natural gas in the system. It was estimated that the share of renewable energy will decrease to $\% 9$ of TPES in 2020 (IEA, 2005).

As seen from Figure 6, the share of installed renewable capacity in total installed capacity dramatically decreased in the last decade.

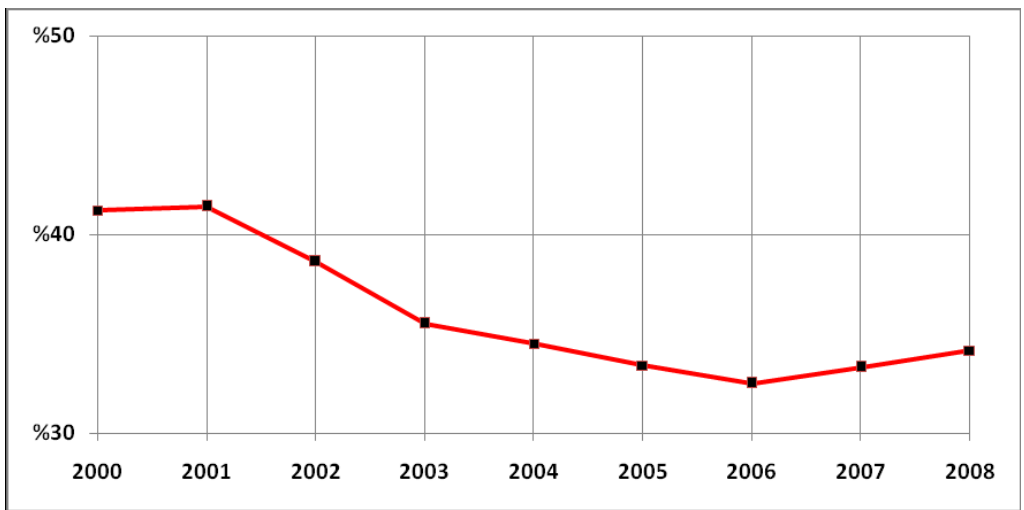

Fig. 6. The Share of the installed capacity of the renewable energy resources including large hydro, within the total installed capacity (\%) (MENR, 2010\}.

Although the absolute value of renewable energy use grows, since it doesn't grow at the same proportion with energy consumption, the share of fossil fuels continues to increase (Saygın \& Çetin, 2010). This fact can also be seen from Figures 7-8 illustrating Turkey's primary energy supply and electricity generation by fuels.

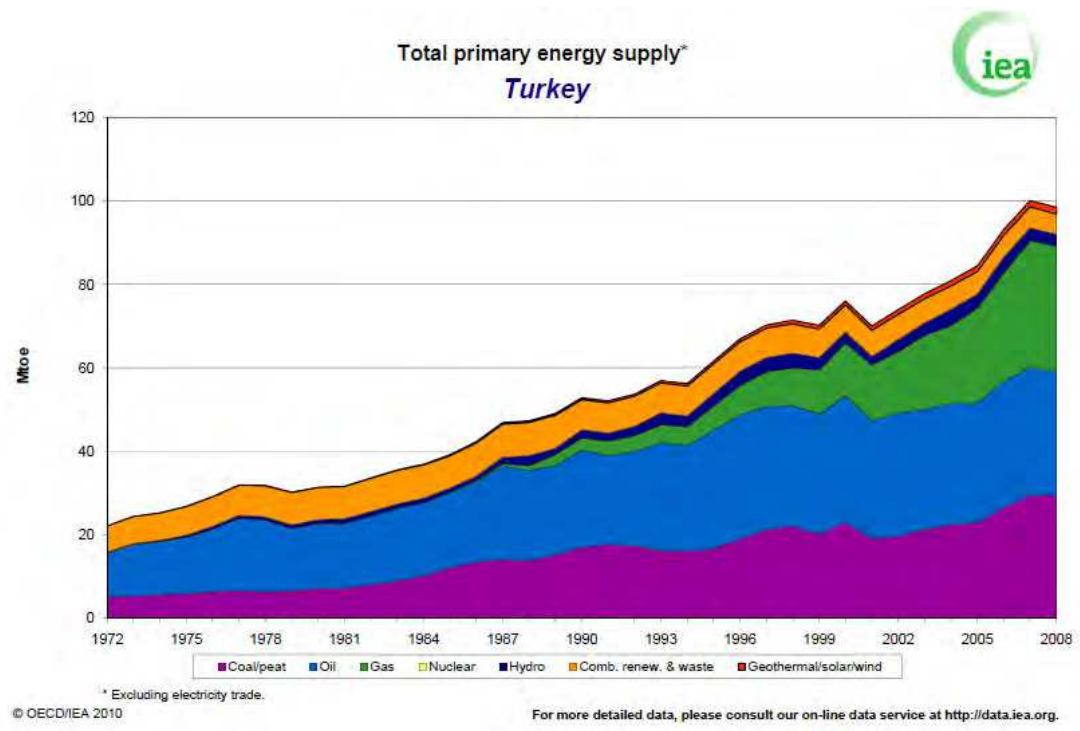

Fig. 7. Turkey's total energy supply by fuel in the period 1972-2008 (IEA, 2009). 


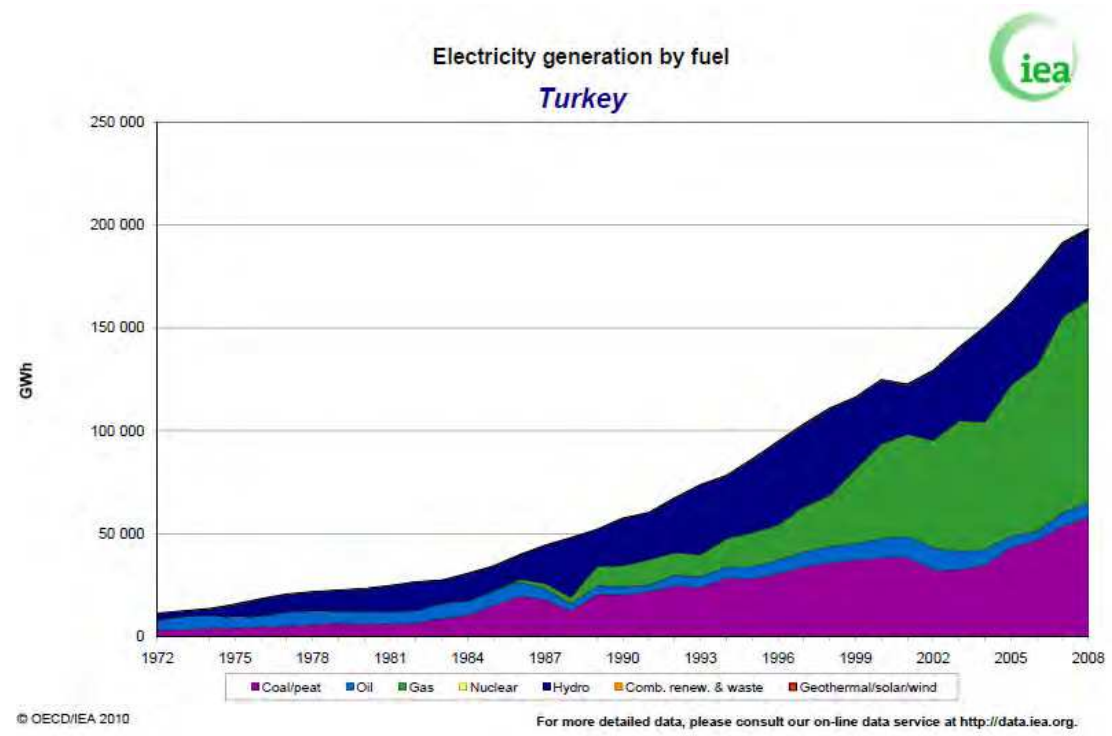

Fig. 8. Evolution of Turkey's electricity generation by fuels (IEA, 2009).

Environmental and energy security risks are therefore more and more increasing for the Country. The energy situation of Turkey is characterized by high rate of import dependence, high energy intensity, rapidly rising greenhouse gas emissions. This situation is evidently unsustainable and in conflict with the contemporary global trends. Turkey is faced with serious environmental and energy security challenges presently. Additionally, it needs for high amounts of financial resources for energy investment to meet growing energy demand. Limitations within the scope of harmonization with the EU cause the cost of energy investments to rise and complicate the situation further. All of these are matters of concern for decision makers of the Country (Saygın \& Çetin, 2010).

It is clear that, the existing renewable energy potential should be realized in a reasonable time period. To realize renewable potential, Turkey has taken some steps in the right direction. Although it has been made important progress with regard to renewable energy, energy efficiency and market liberalization regulations in the recent years; new paradigm is slowly diffusing into Turkey's energy policies and the regulations due to strong concerns related with energy supply security[(Saygın \& Çetin, 2010).

\section{Recent developments in renewable energy policy and regulations}

Although, The Renewable Energy Law and its subsequent amendments are the main pieces of legislation supporting the development of renewable energy, The Electricity Market Law and the Energy Efficiency Law are also major relevant pieces of the Legislation. Together with these Laws, related secondary legislation, regulations and supporting regulations, like Electricity Market Licensing Regulation, set the legal framework for promoting electricity generation from renewables and including main instruments. They offer some advantages like feed-in tariff and purchase obligations, connection priority, reduced license fees, exemption from license and company establishment obligations for the plants with a 
maximum capacity of $500 \mathrm{~kW}$, reduced land use fees or free land use. (EUMS, 2009). The Turkey's legislation on renewable energy established within the last decade (Table 1).

\begin{tabular}{|c|c|}
\hline Date & Legislation \\
\hline 2001: & Electricity Market Law (No:4628) \\
\hline 2002 & Electricity Market Licensing Regulation \\
\hline 2003 & Petroleum Market Law (No:5015) \\
\hline 2004 & Strategy Paper as Road Map of the Electricity Market Reform \& Transition \\
\hline 2005 & Law on Utilization of Renewables in Electricity Generation \\
\hline 2007 & $\begin{array}{l}\text { Energy Efficiency Law (No:5627) } \\
\text { Amendments to the Law on Utilization of Renewables in Electricity } \\
\text { Generation (No:5346) } \\
\text { Geothermal Law (No:5686) }\end{array}$ \\
\hline 2008 & Significant Amendments to the Electricity Market Law (No:5784) \\
\hline 2009 & Strategy Paper on Electricity Market Reform, \& Security of Supply \\
\hline 2011 & $\begin{array}{l}\text { Amended Law on Utilization of Renewables in Electricity Generation (No. } \\
6094 \text { ) }\end{array}$ \\
\hline
\end{tabular}

Table 1. Renewable energy -related legislation (Çetin, 2010).

The Electricity Market Law and Electricity Market Licensing Regulation entered into force in 2001 and 2002, respectively, also set forth a number of pro-renewables provisions (TR, 2001; TR,2002). Turkey enacted its first law specific to renewable energy, the Law on the Utilization of Renewable Energy Sources for the Purpose of Generating Electrical Energy (the Renewable Energy Law) with No. 5346, on 18 May 2005 (TR, 2005). This was a key step for strengthening the country's renewable energy sector. According to this Law, the legal entity holding generation license shall be granted by EMRA with a "Renewable Energy Resource Certificate" (RES Certificate) for the purpose of identification and monitoring of the resource type in purchasing and sale of the electrical energy generated from renewable energy resources in the domestic and international markets. This Law provides feed in tariff until 2011, purchase guarantee. In addition, State territories are permitted on the basis of its sale price, rented, given right of access or usage permission by Ministry of Environment and Forestry or Ministry of Finance. Fifty percent deduction is implemented for permission, rent, and right of access and usage permission in the investment period. Following the enactment of the first Renewable Energy Law, investors showed an increasing interest in Renewables, especially in relation to the generation of electricity through hydro plants and wind farms (Saygin \& Çetin, 2010). However, the interest in renewable energy projects was hindered by the lenders' reluctance because of the uncertainty in the purchase guarantees. As a result, the government introduced an important series of amendments in 2007 and 2008(TR, 2007; TR, 2008). The amendment to the Law in May 2007 secured a constant purchase price for all types of renewable sources (Saygin\& Cetin, 2010). Together with the Amendment in 2008 entered into force following incentives are offered by Renewable Energy Law to promote renewable energy (TR,2008; EUMS, 2009; Gümüş, 2011; Kolcuoğlu, 2011).

For Renewable Power Plants (PPs) in operation for not longer than 10 years:

- The average electricity wholesale price of the previous year is to be determined by EMRA and limited to €cent 5-5.5/kWh RES, 
- Certificate owners are also granted the right to sell their output at higher rates whenever available in the spot market or via bilateral contracts with eligible customers,

- The share of renewable output within the retail licensees' portfolio cannot be less than their domestic market share.

During the first 10 years of operation, an $85 \%$ deduction is applied to fees related to permission, rent, and right of access and usage permission over the investment and operation period, in the event of the use of the property under the possession of the General Directorate of Forestry or the Treasury.

$85 \%$ deduction is applied to fees related to investments in the transportation infrastructure and power lines until the connection point to the grid.

Exemption from the special fees charged to contribute to the development of woodland villages, promotion of forestation and erosion mitigation.

Free use of state-owned estates located within the reservoir of Hydroelectric Power Plants holding a RES Certificate.

Following the enactment of the Amended Renewable Energy Law in 2007, investor interest in the renewable energy sector has risen distinctively, and a significant progress has been made. The efforts successfully resulted in an appreciable increase in the share of renewables excluding large- hydro in total especially in the wind and geothermal capacities, as seen from Figure 9.

Despite this hopeful development in hydro, wind and geothermal energy, solar capacity has not developed and clearly needs further promotion. By this aim, a New Amendment to Renewable Energy Law was supposed, therefore, to the National General Assembly on June, 2009. It was suspended until recently since it would create an extra burden on the treasury (Saygin \& Çetin, 2010).

\begin{tabular}{ccccc}
\hline Energy source & $\begin{array}{c}\text { Generation. } \\
\text { [TWh] }\end{array}$ & Share, \% & $\begin{array}{c}\text { Capacity, } \\
\text { [MW] }\end{array}$ & $\begin{array}{c}\text { Share, } \\
\%\end{array}$ \\
\hline Natural gas & 94.4 & 48.6 & 16345.2 & 19.4 \\
\hline Domestic Coal & 42.2 & 21.7 & 8691.3 & 19.4 \\
\hline İmported Coal & 12.8 & 6.6 & 1921. & 4.3 \\
\hline $\begin{array}{c}\text { Hydropower } \\
\text { Liquid fuels } \\
\text { (Oil) }\end{array}$ & 35.9 & 18.5 & 14553.4 & 32.5 \\
$\begin{array}{c}\text { Wind \& } \\
\text { Geothermal, } \\
\text { Biogas }\end{array}$ & 6.6 & 3.4 & 2309.7 & 5.2 \\
\hline TOTAL & 194.1 & 1.1 & 961.2 & 2.1 \\
\hline
\end{tabular}

Table 2. Turkey's installed capacity and power generation by fuel (Çetin, 2010).

By 2009, renewable sources provided 37.8 TWh of electricity, or $19.6 \%$ of the total power generation in Turkey. Hydropower accounted for $95 \%$ (35.9 TWh) of this total, wind power for $4 \%(1.5 \mathrm{TWh})$, biomass and geothermal for $\% 1(0.5 \mathrm{TWh})$. The Country is the $12^{\text {th }}$ highest share among the 28 IEA countries (IEA, 2009). 


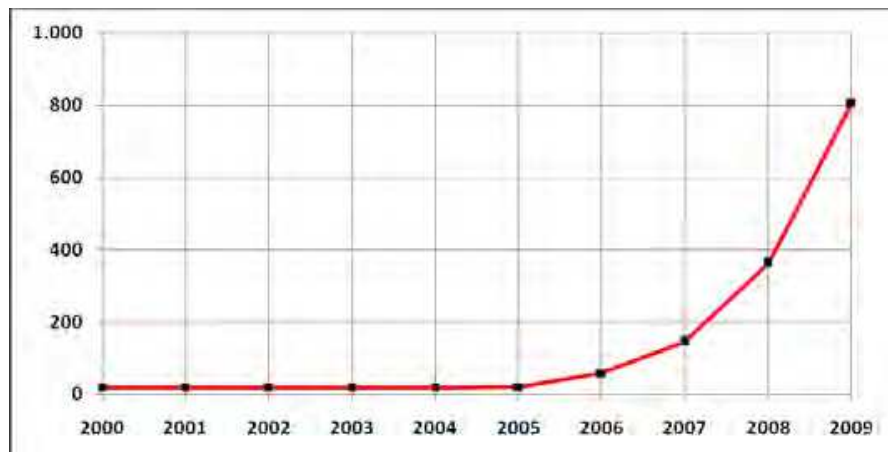

(a)

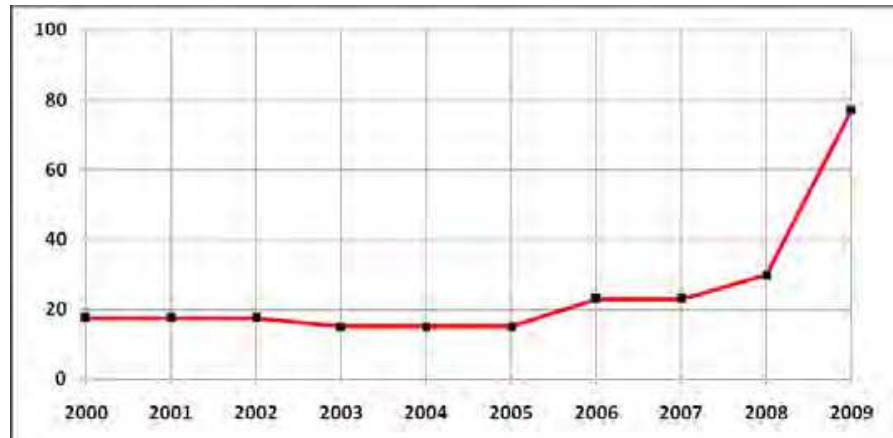

(b)

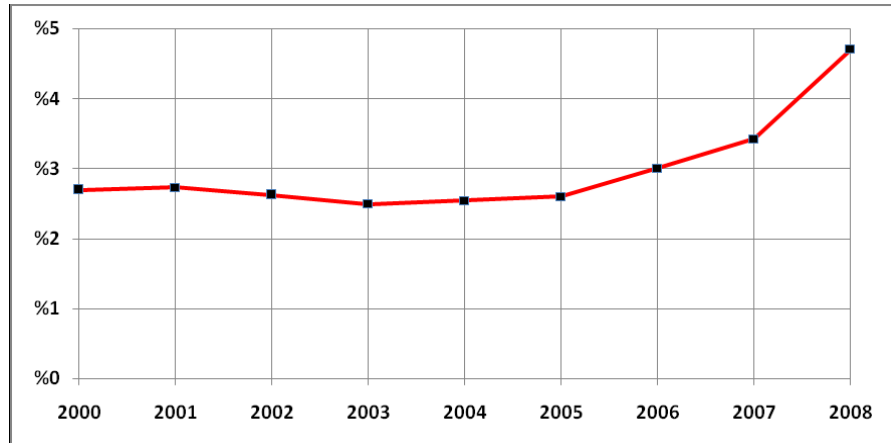

(c)

Fig. 9. In Turkey, evaluation of a) installed wind power capacity, b) installed geothermal capacity, c) the share of renewables excluding large- hydro (MENR, 2010).

A total of 601 renewable projects with a capacity of 15500 MW had been licensed by 2009(Saygin \& Çetin, 2010). This number has reached to 645 by 2010. The number of licensed power plants according to energy sources is given in the Figure 10 


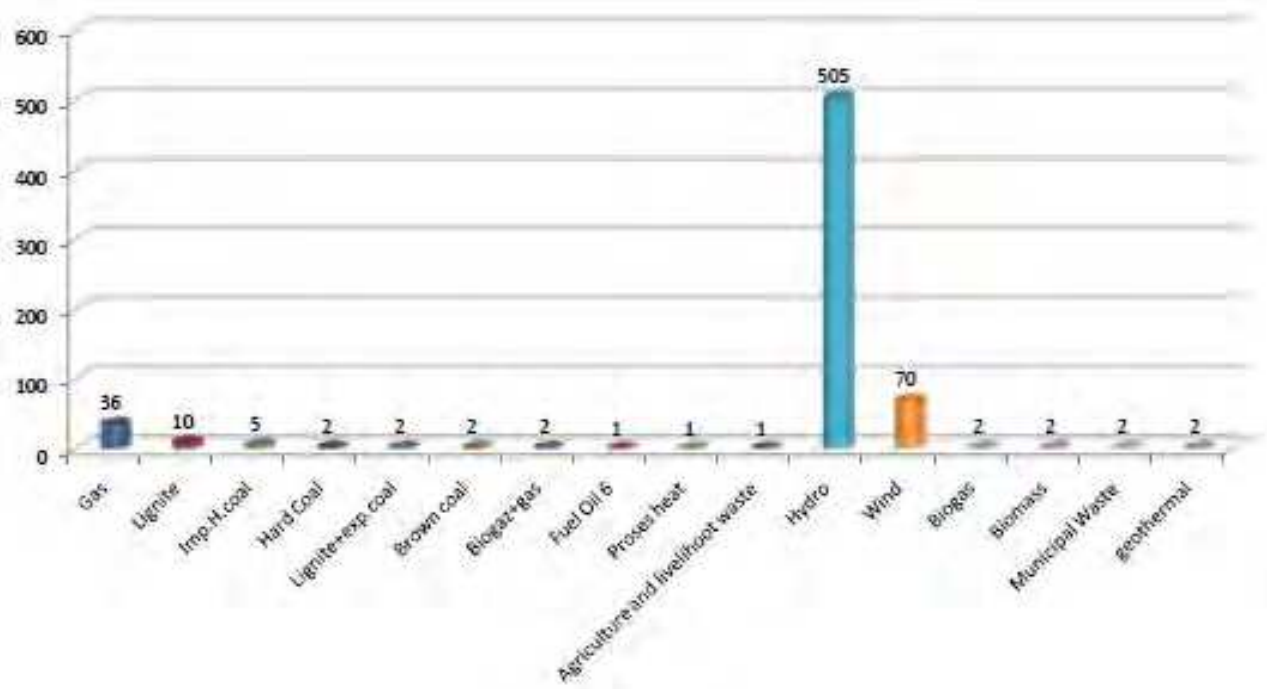

Fig. 10. Number of the power plants licensed by 2010, total 645(Çetin, 2010).

As can be seen from this figure, Hydroelectric, and wind power plant hopefully left behind the others. This implies promotion policy for renewable energy started to be effective.

Despite these progressive steps forward, most of the huge renewable potential of Turkey has not been used yet, as can be seen from Figure 11.

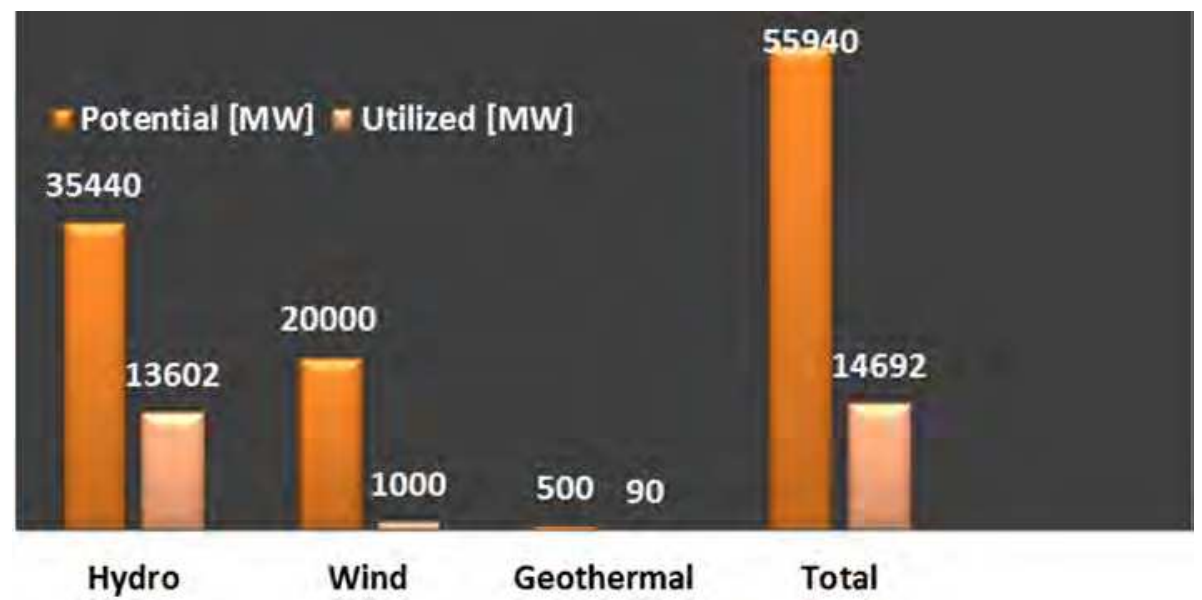

Fig. 11. Utilization Rates of Renewable Energy Potential in Turkey[6]

On 29 December 2010, the Turkish Parliament finally passed this Amendment Law upgrading and differentiating feed-in tariff structure with regards to sources. As seen from the Table 3, the Law guarantees prices of 7.3 US cents per kilowatt-hour for hydroelectric and wind, a price of 10.5 US cents for geothermal energy. a price of 13.3 US cents for solar energy as well as waste products (such as biomass or municipal solid 
waste-to-energy projects). As can be understood, it has been especially aimed to promote solar energy by this amendment. Under the last Amended Renewable Energy Law, individuals and legal entities generating electricity from renewable resources are able to benefit from this feed-in tariffs, provided that they allocate any excess amount of generated electricity to the national electricity distribution system. This will be applicable for a period of 10 years for generation license holders who are subject to RES support mechanism and have commenced/will commence operations between 18 May 2005 and 31 December 2015 (TR, 2010).

\section{Plant Type \\ Purchase price for produced electricity USD cents/kWh}

\begin{tabular}{ll}
\hline Hydro & 7.3
\end{tabular}

Wind

7.3

Geothermal

10.5

Biomass

13.3

Solar

Table 3. Feed in Tariff for Renewables (TR, 2010).

The Law also offers add payment for components made in Turkey. If the mechanical and electro-mechanical equipment used in renewable energy facilities that have started operation before 31 December 2015 are manufactured in Turkey, an additional incentive of 0.4-2.4 USD/cent for five years will be provided. In addition EMRA will give priority to facilities generating energy from renewable resources in evaluating generation license applications. In addition, The Amendment Renewable Law offers Incentives through the Pooling of Payments: It envisages a pool managed by the Market Financial Settlement Centre (MFSC) whereby the electricity suppliers will make the payment of the renewable energy and the renewable energy generators will collect their fees (TR, 2011; Kolcuoğlu, 2011).

Other incentives provided in the legislation are as follows:

- Legal entities applying for a license for the construction of facilities based on domestic natural resources and RES shall only pay 1 per cent of the total licensing fee.

- Generation facilities based on renewable and domestic energy resources shall not pay annual license fees for the first eight years following the facility completion date inserted in their respective license.

- $\quad$ TEIAS, the State Owned Transmission Company, and distribution licensees shall give priority to the system connection of generation facilities based on domestic natural resources and renewable resources.

If the price of electricity generated at facilities based on RES is equal to or lower than the sales price of TETAS, the state owned wholesale company, and if there is no cheaper 
alternative, the retail licensees are obliged to purchase the electricity generated at facilities based on RES for the purposes of resale to non-eligible consumers.

With the passing of the amendments to the Turkish Renewable Energy Law in December 2010, more progressive development in renewable energy sector can be expected. Although none of the legislation fully met the needs of renewable energy investors - until now and the incentives provided for renewable energy investments are criticized by the investors since the feed-in tariffs are lower than expected, a certain progress have been made. The efforts made so far are hopeful; however it seems there are more steps to be taken.

\section{Place of renewables in Turkey's near and long term energy strategy}

Presently, Turkey is at the stage of setting targets of renewable energy development. The Higher Board of Planning adopted the "Electric Energy Market and Supply Security Strategy Paper for long term target in May 2009 (MENR, 2009). In this Strategy Paper, the long term primary target is determined as "to ensure that the share of renewable resources in electricity generation is increased up to at least 30\% by 2023 (MENR, 2010)

This strategy document published as a general road map of increasing the share of renewable energy in electricity generation.

Within the framework of the Strategy Paper, long term works will take into consideration the following targets, by 2023(MENR, 2010):

- It will be ensured that technically and economically available hydro-electric potential is entirely put to use,

- It is targeted to increase installed wind energy power to 20, $000 \mathrm{MW}$,

- Turkey's geothermal potential of $600 \mathrm{MW}$, which is presently established as suitable for electric production, is entirely commissioned by 2023.

- It is targeted to generalize the use of solar energy for generating energy, ensuring maximum utilization of country potential. Regarding the use of solar energy for electricity generation, technological advances will be closely followed and implemented.

- Preparation of production Plans will take into account potential changes in utilization potentials of other renewable energy resources based on technological and legislative developments and in case of increases utilization of such resources, share of fossil fuels and particularly of imported resource, will be reduced accordingly.

For determining near-term targets, Ministry of Energy and Natural Resources prepared a Strategic Plan covering the period between 2010 and 2014 (MENR, 2010), which is given in Table 4 . For the purpose of increasing the energy supply security, the resources, routes and technologies will be diversified. Beside energy efficiency, increasing use of renewables and the integration of nuclear energy into energy mix are the two main components of new energy policies of Turkey. According to the Plan's aim of providing diversification of the energy supply, the maximum use of the domestic and renewable resources in the production of electricity energy and the initiation of the construction of the nuclear plant have been targeted.

It should be emphasized that both of this long term and near term strategy plans are not, on their own, legally binding. It is, however, expected that their provisions will be incorporated into future regulations and legislation. 
THE REPUBLIC OF TURKEY MINISTRY OF ENERGY AND NATURAL

RESOURCES STRATEGIC PLAN (2010-2014)

Aims For Energy Supply Security

1. Providing Diversity in Resources by Giving Priority to the Domestic Resources Target 1.1 Within the period of the Plan, the domestic oil, natural gas and coal exploration works will be increased.

Target 1.2 The domestic coal thermal plants of 3,500 Mega Watt (MW) will be completed by 2013.

Target 1.3 By the year 2014, the construction of nuclear plant will start.

2. Increasing the share of the renewable energy resources within the energy supply Target 2.1 The construction of The hydroelectricity plants of 5,000 MW, will be completed by 2013.

Target 2.2 The wind plant installed capacity, which has been $802,8 \mathrm{MW}$ as of 2009 will be increased up to 10,000 MW by 2015 .

Target 2.3 The installed capacity for the geothermal plant of 77,2 MW in 2009, will be increased up to $300 \mathrm{MW}$ until 2015.

3. Increasing Energy Efficiency

Target 3.1 Within framework of the energy efficiency studies, $10 \%$ reduction in energy consumption will be secured by 2015 in comparison to 2008 .

Target 3.2 The completion of the maintenance, rehabilitation and modernization studies conducted for increasing the efficiency and production capacity through the use of new technologies in the existing state owned electricity production plants by the end of 2014 will be secured.

4. Making the free market conditions operate fully and providing for the improvement of the investment environment

Target 4.1 By the year 2014, the targeted privatizations in the electricity sector will be completed.

Target 4.2 By the year 2015, the formation of the market structure that works as based on competition will be secured.

Target 4.3 By the year 2015, the formation of the market structure that works as based on competition will be secured in the natural gas sector.

5. Providing the diversity of resources in the area of oil and natural gas and taking the measures for reducing the risks due to importation

Target 5.1 By the year 2015, the foreign crude oil and natural gas production will be redoubled in comparison to the production amounts in 2008.

Target 5.2 The existing natural gas storage capacity which is 2,1 billion $\mathrm{m}^{3}$ in 2009 will be redoubled by 2015 .

Target 5.3 In natural gas importation, by the year 2015, we will decrease the share of the country from which the highest amount of importation is made and the diversity of source countries will be provided.

Target 5.4 The sustainability of the storage of the national oil stocks at a secure level will be provided.

Table 4. Turkey's near term Strategic Plan for the Period 2010-2014(MENR, 2010). 


\section{Renewable energy projects}

Turkey is within some projects for reaching its aims related to renewable energy. The most important one of them is The Private Sector Renewable Energy and Energy Efficiency Project. The Project aims to help increase privately owned and operated energy production from indigenous renewable sources within the market-based framework of the Turkish Electricity Market Law, thereby helping to enhance energy efficiency and curb greenhouse gas emissions as a result. The project is the first to use resources from the newly established Clean Technology Fund (CTF) - a new US\$5.2 billion multilateral fund managed by the World Bank and administered through the World Bank Group and other multilateral development banks. World Bank and CTF financing for the project will include two loans, one from the IBRD and one from the CTF, each to two Turkish development banks: Türkiye Sinai Kalkınma Bankası (TSKB) the Turkish Industrial Development Bank (private) and Türkiye Kalkınma Bankası (TKB) the Turkish Development Bank (government) - for credit line financing of renewable energy and energy-efficiency investments(WB, 2011).

Another important Project is Renewable Energy Networks (RENET) between Turkish and European Universities. The project allows the combination of best available technology information in the field of renewable energy and best practices transfer in higher education and science and Technology co-operation.

The specific objectives of the RENET project are to (RENET, 2011):

i. enhance the awareness and understanding of academic staff as well as of policy-makers and stakeholders of the political, economical and social frameworks relating renewable energy;

ii. promote the Information and Technology Transfer for renewable energies;

iii. increase the capacity of the academic community to participate in Turkish-European cooperation projects, and

iv. foster the strategic partnership for implementing renewable energies in Turkey and the EU.

It is expected that RENET will provide a relevant contribution not only to the Millennium Development Goals (MDGs) on ensuring environmental sustainability and developing global partnerships for development. Moreover, it is also in line with the strategic objectives of the Lisbon-Gothenburg Strategy of the European Union(RENET, 2011).

\section{Conclusions}

Turkish energy market is currently the scene of important changes. The Country established a new national energy plan based on diversification of supplies, the start of nuclear energy production and development of renewable energy and energy efficiency. It seems to move towards a low carbon energy sector: In this context, it has three main strategies: increasing energy efficiency and renewable energy use in addition increasing natural gas use. This implies Turkey is stepping up its engagement on climate change internationally and nationally.

It has taken some important steps to promote the use of renewable energy resources. The Country's renewable energy policies are in a consistency with EU Energy Policies and global trends like energy efficiency and market liberalization policies. It is clearly seen the country is heading in the right direction. However, its deliberate policy has caused relatively slow progress in the realization of its aims. This may cause Turkey to miss the technological 
leapfrogging (Saygin, 2006) opportunity presented by emerging paradigm for developing countries. In this context, Turkey has remained behind other leading developing countries like China and India.

\section{References}

Çalıkoğlu, E. (2007).Energy Efficiency in Turkey, TAIEX Workshop 25625 on Demand Side Management in Energy Efficiency, 22-23 November 2007, Turkey, Available from http://www.eie.gov.tr/duyurular/EV/TAIEX/ErdalCalikoglu_TAIEXWorkshop2 5625onDSM_221107.pdf.

Çetin, H. (2010).Turkish Energy Sector ,UNECE-e8-EBRD-WEC Fostering Investment in Electricity Generation in Central and Eastern Europe and Central Asia, November 2224, 2010, Geneva, Switzerland, Available from http:/ / www.google.com.tr/webhp?hl=tr\#hl=tr\&source=hp\&q=Turkish+Energy+ Sector+\%2CUNECE-e8-EBRD-.

EUMS (Energy, Utilities \& Mining Sector ), (2009) Renewables Report On the sunny side of the street* Opportunities and challenges in the Turkish renewable energy market Industries, Available from www.boell-meo.org/downloads/Renewable_Energy_Turkey.pdf.

Gümüş, S.,(2011) ,Turkey: Incentives For Renewable Energy, Energy \& Natural Resources, on 28 April 2011. Available from http://www.mondaq.com/x/130778/Renewables/Incentives+For+Renewable+ Energy.

IEA(2009), Energy Policies of IEA Countries, Turkey Review 2009, Paris, France.

Kolcuoglu D.(2011). Incentives under the Long-Awaited Renewable Energy Law - Turkey, HG.org, Available from http:/ / www.hg.org/article.asp?id=20931.

MENR (2009), Turkey's Electric Energy Market and Supply Security Strategy Paper with Res. No. 2009/11, dated 18.09.2009, Available from http://www.enerji.gov.tr/yayinlar_raporlar/Arz_Guvenligi_Strateji_Belgesi.pdf.

MENR (2010). The Republic of Turkey Ministry of Energy and Natural Resources Strategy Plan 2010-2014, Ankara, Turkey.

Observatoire Mediterraneen de l'Energie (OME),(2008) Mediterranean Energy Perspectives 2008.

Özçaldıran, K (2010). A profile of Turkish Energy Sector and related greenhouse gas emission", The Symposium on Global Energy Future, 1-5 October, 2010, St. Louis, USA.

Saygin, H. (2006). Technological leapfrogging in energy in developing countries (in Turkish)", Enerji, Vol.11, No.1, pp. 27.

Saygin, H. and Cetin F. (2010). New energy paradigm and renewable energy:Turkey's vision, Insight Turkey, Vol. 12, No. , pp. 107-128.

TR (2001). The Electricity Market Law No. 4628, Official Gazette, No. 24335, March 2001.

TR (Republic of Turkey), (2005). Law on Utilization of Renewable Energy Sources for the Purpose of Generating Electrical Energy, Official Gazette, with No. 24335, dated 10.05.2005 (Law No.: 5346).

TR, (2007). The Law Amending the Law on Utilization of Renewable Energy Resources in Electricity Generation , Official Gazette , with No. 26510, dated 02.05.2007. 
TR, (2008).The Law Amending the Law on Utilization of Renewable Energy Resources in Electricity Generation Law on Utilization of Renewable Energy Sources for the Purpose of Generation Electricity, Official Gazette, No. 270522, dated 03.12.2008.

TR, (2011). The Law Amending the Law on Utilization of Renewable Energy Resources in Electricity Generation (Law No: 6094), Official Gazette dated 8 January 2011 and numbered 27809.

WB (World Bank), (2011). Turkey: Private Sector Renewable Energy and Energy Efficiency Project, Available from

http://www.worldbank.org.tr/WBSITE/EXTERNAL/COUNTRIES/ECAEXT/TU RKEYEXTN/0,,contentMDK:22244557 menuPK:361754 pagePK:2865066 piPK:28 65079 theSitePK:361712,00.html.

RENET,(2011). Renewable Energy Networks between Turkish and European Universities, Available from http://www.renet-project.eu/. 


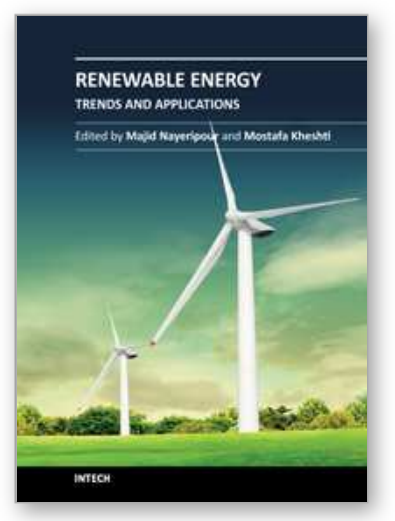

\author{
Renewable Energy - Trends and Applications \\ Edited by Dr. Majid Nayeripour
}

ISBN 978-953-307-939-4

Hard cover, 250 pages

Publisher InTech

Published online 09, November, 2011

Published in print edition November, 2011

Increase in electricity demand and environmental issues resulted in fast development of energy production from renewable resources. In the long term, application of RES can guarantee the ecologically sustainable energy supply. This book indicates recent trends and developments of renewable energy resources that organized in 11 chapters. It can be a source of information and basis for discussion for readers with different backgrounds.

\title{
How to reference
}

In order to correctly reference this scholarly work, feel free to copy and paste the following:

Hasan Saygın and Füsun Çetin (2011). Recent Developments in Renewable Energy Policies of Turkey, Renewable Energy - Trends and Applications, Dr. Majid Nayeripour (Ed.), ISBN: 978-953-307-939-4, InTech, Available from: http://www.intechopen.com/books/renewable-energy-trends-and-applications/recentdevelopments-in-renewable-energy-policies-of-turkey

\section{INTECH}

open science | open minds

\section{InTech Europe}

University Campus STeP Ri

Slavka Krautzeka 83/A

51000 Rijeka, Croatia

Phone: +385 (51) 770447

Fax: +385 (51) 686166

www.intechopen.com

\section{InTech China}

Unit 405, Office Block, Hotel Equatorial Shanghai

No.65, Yan An Road (West), Shanghai, 200040, China

中国上海市延安西路65号上海国际贵都大饭店办公楼 405 单元

Phone: +86-21-62489820

Fax: $+86-21-62489821$ 
(C) 2011 The Author(s). Licensee IntechOpen. This is an open access article distributed under the terms of the Creative Commons Attribution 3.0 License, which permits unrestricted use, distribution, and reproduction in any medium, provided the original work is properly cited. 